wie praktische Hinweise über Temperaturmessung mit Widerstandsthermometern und Thermoelementen.

Im Anhang finden sich Spannungsreihen für Thermoelemente und Grundwerte für Pt100.

Die überarbeitete Neuerscheinung können Sie gegen eine Schutzgebühr von
14,-- EUR unter der Bestellnummer 000747750 oder direkt über das Internet unter www.jumo.net bestellen.

Dort finden Sie ebenfalls weitere Fachpublikationen aus dem Hause JUMO.

Information:

M. K. Juchheim GmbH \& Co.

36035 Fulda, Germany

\title{
Erratum
}

\section{Simple HPLC Method for Simultaneous Determination of Acetaminophen, Caffeine and Chlorpheniramine Maleate in Tablet Formulations}

\section{by M. L. Qi / P.Wang / Y.X. Leng / J. L. Gu / R. N. Fu}

published in Vol. 56, pp. 295-298(2002)

On p. 296 in the section "Instrumentation" there is an error in regard to the analytical column and should read: Hypersil CN $(150 \times 5.0 \mathrm{~mm}, 5 \mu \mathrm{m})$ 